Ann. rheum. Dis. (1969), 28, 402

\title{
SYNOVIAL MEMBRANE IN EXPERIMENTALLY-PRODUCED CHRONIC HAEMARTHROSIS
}

\author{
BY \\ S. ROY ${ }^{1 *}$ AND F. N. GHADIALLY ${ }^{2}$ \\ From the ${ }^{1}$ Department of Pathology, University of Sheffield, England, and the ${ }^{2}$ Department of Pathology, \\ University of Saskatchewan, Canada
}

The gross and light microscopical changes that occur in the synovial membrane in human chronic haemarthrosis are well documented (Key, 1932; Ghormley and Clegg, 1948; Collins, 1951; De Palma and Cotler, 1956; Rodnan, Brower, Hellstrom, Didisheim, and Lewis, 1959) and virtually every change seen in man has been reproduced in the experimental animal (Key, 1929; Young and Hudacek, 1954; Wolf and Mankin, 1965; Hoaglund, 1967), but no ultrastructural studies of chronic haemarthrotic joints in man or experimental animals have as yet been reported.

Recently we described the ultrastructural changes that occur in acute haemarthrotic joints in man (Roy and Ghadially, 1967) and rabbit (Roy and Ghadially, 1966). We have now studied the changes that occur in the synovial membrane in experimentally produced chronic haemarthrosis in the rabbit and the results are reported in this paper.

\section{Material and Methods}

Eighteen normal male rabbits with initial weight of about $2 \mathrm{~kg}$. were used in this experiment. All the animals received a once weekly injection of $1-1.2 \mathrm{ml}$. autologous blood into the right knee joint; the left knee served as control. Details of injection technique and the methods employed in collecting and preparing synovial membrane for electron microscopy have already been described (Roy and Ghadially, 1966) and will not be repeated here.

The animals were divided into five groups. The Table shows the total number of injections of blood given (one injection per week) to each animal and the interval allowed to elapse between the last injection and the killing of the animal and the collection of the tissues.

Light microscopical studies of synovial membrane from both control and injected joints were also executed. Histological sections were stained with haematoxylin and eosin, Prussian blue reaction for iron, and methyl green-pyronin stain for ribonucleic acid.

- Present address for reprints: Department of Pathology, All-India Institute of Medical Sciences, Medical Enclave, New Delhi 16, India.

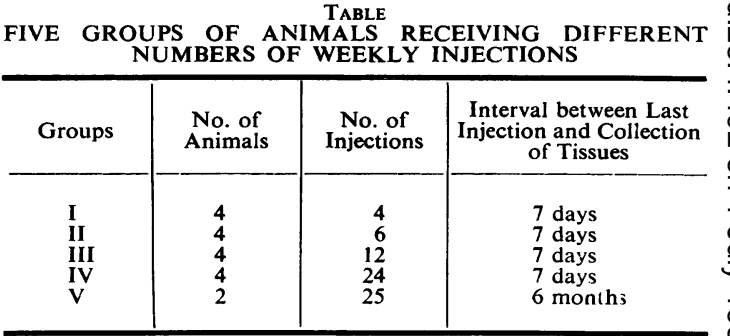

\section{Results}

\section{Macroscopical Changes}

No free blood was found in the knee joints when the animals were killed. The synovial membrane appeared thickened and showed a brownish tint. These changes were most marked in Groups III and IV animals. The synovial membrane of Group V animals was fibrotic.

\section{Light Microscopical Changes}

The main changes seen in the synovial membranes from injected joints as compared with the normal were: (1) synovial cell hyperplasia, (2) chronic inflammatory cellular infiltration of subsynovial tissue and fibrosis, (3) haemosiderosis.

(1) Synovial Cell Hyperplasia.-All animals except those belonging to Group $\mathrm{V}$ showed an increased thickness of synovial intima due to an increase in both the size and the number of synovial cells (Fig. 1, opposite).

This change was most marked in Group IV animals. Villous formations (Fig. 2) and folds of synovial cells invaginating into the sub synovial tissue forming "clefts" (Fig. 3, opposite) were also encountered.

The synovial cells of Group V animals were flattened and atrophic (Fig. 4, overleaf). The results of methyl green-pyronin staining for RNA clearly demonstrated an increase in the staining intensity and number of RNA-positive synovial cells in all animals except those belonging to Group V. 
Fig. 1.-Synovial membrane from an animal which had received 24 weekly injections of blood (Group IV), showing marked hyperplasia of the synovial intima. Haematoxylin and eosin. $\times 310$.

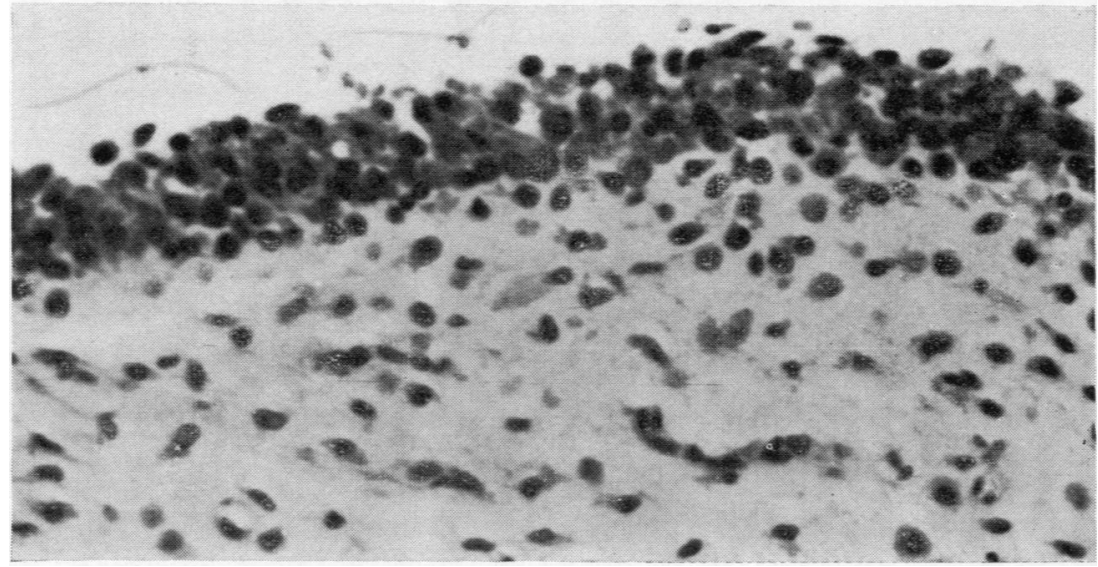

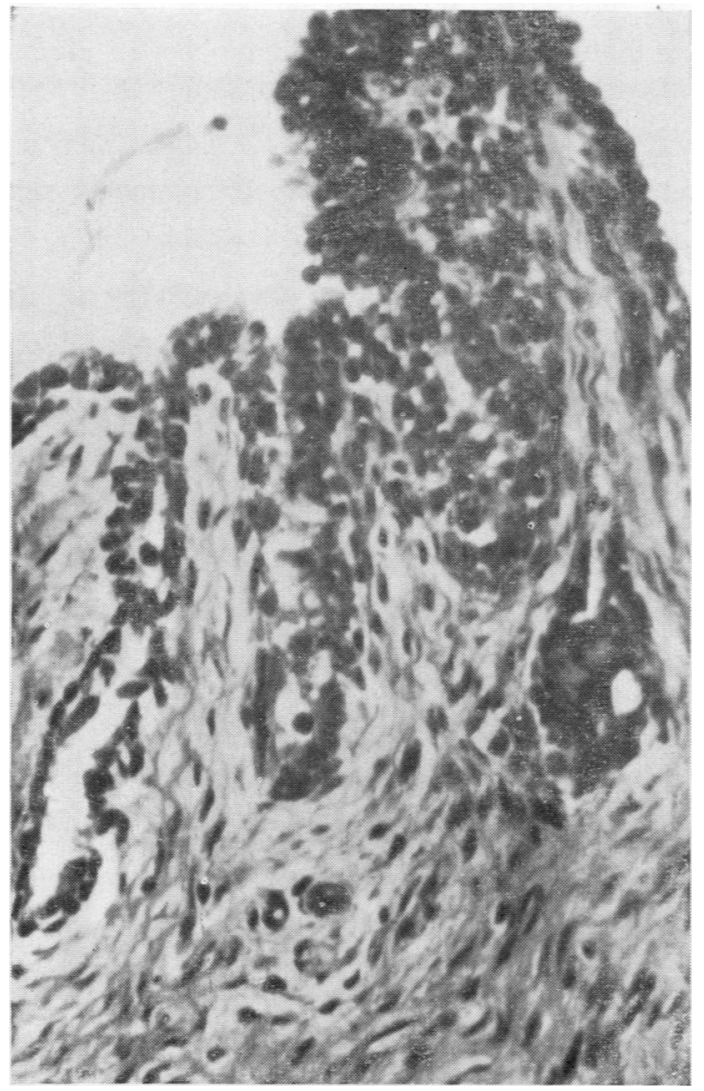

Fig. 2.-Villous proliferation of synovial membrane seen in a Group J' animal. Haematoxylin and eosin. $\times 310$.

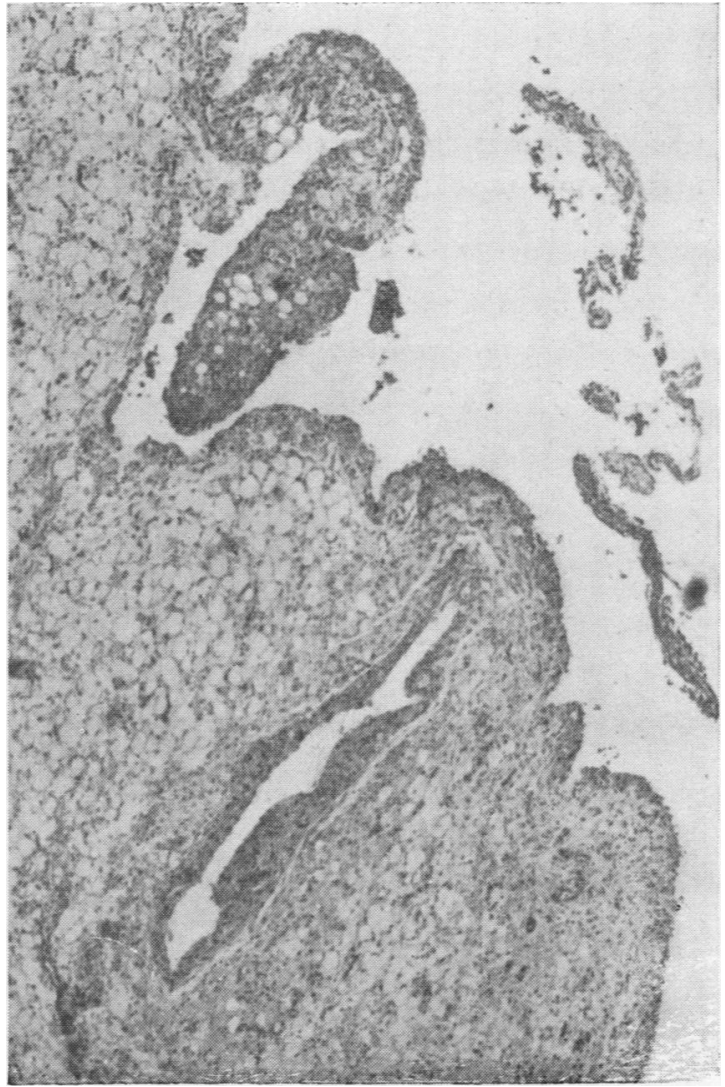

Fig. 3.-Villous and cleft formation seen in synovial membrane of a Group IV animal. Haematoxylin and eosin. $\times 50$. 


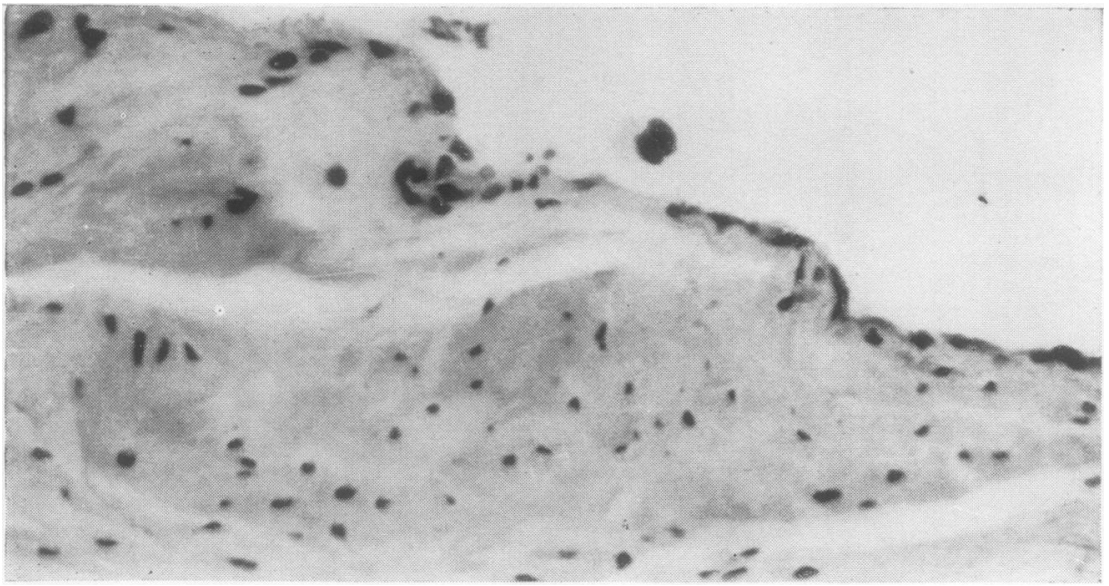

Fig. 4.-Group $\mathrm{V}$ animal. Synovium collected 6 months after cessation of injection regime, showing an atrophic synovial intima and dense fibrosis of subsynovial tissue. Haematoxylin and

(2) Chronic Inflammatory Changes and Fibrosis.Varying degrees of fibrosis and inflammatory cellular infiltration of subsynovial tissues was seen in all injected joints (Fig. 5). The inflammatory infiltrate was best seen in Group III and IV animals, while fibrosis was most marked in Group V animals, where the normal adipose subsynovial tissue found

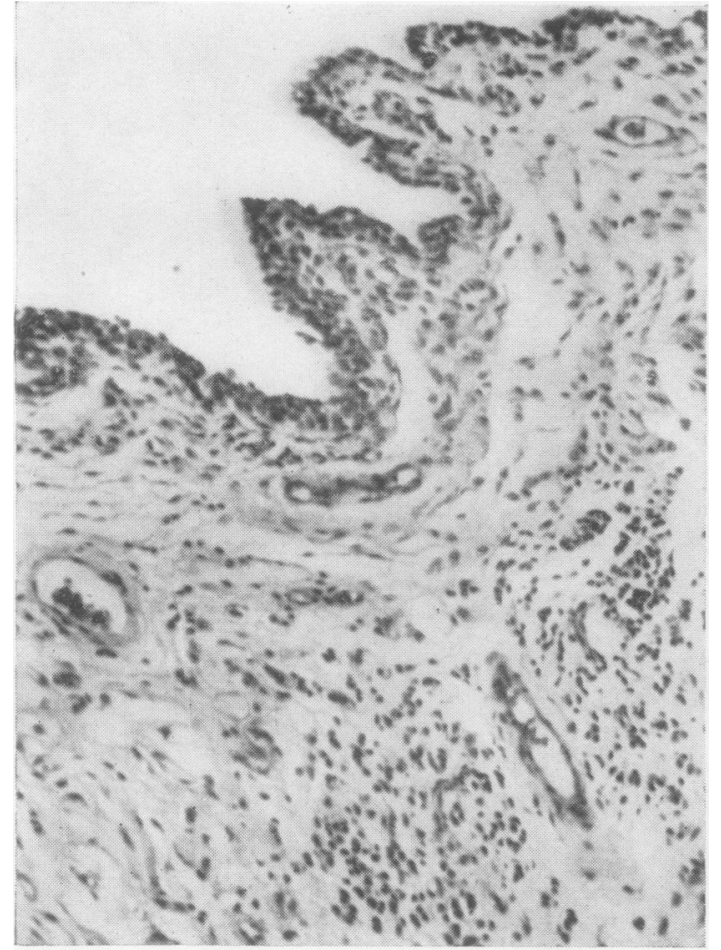

Fig. 5.-Villous formation and infiltration of subsynovial tissues by inflammatory cells in a Group IV animal. Haematoxylin and eosin. in the parapatellar region was almost completely replaced by fibrous tissue. The inflammatory cellular infiltrate was composed of lymphocytes, plasma cells, and histiocytes. In two instances a granulomatous reaction composed of large histiocytes with abundant granular eosinophilic cytoplasm and a few multinucleated giant cells were found in the subsynovial tissue (Fig. 6).

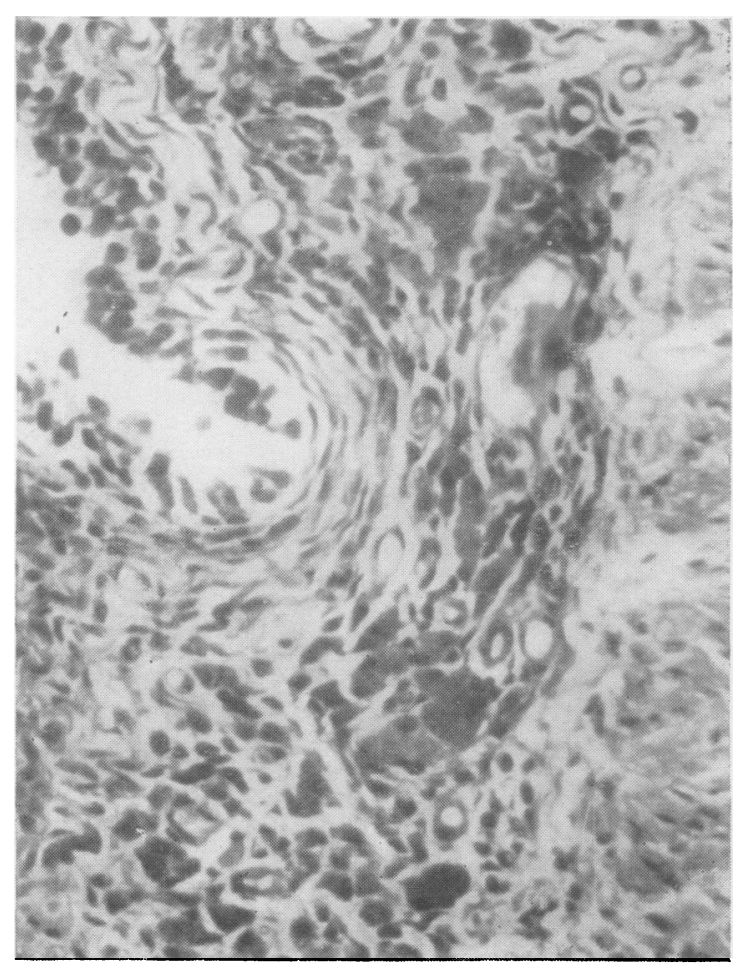

Fig. 6.-Group IV animal, showing a granulomatous reaction in the subsynovial tissue. Histiocytes, giant cells, and fibroblasts can be easily detected. Haematoxylin and eosin. $\times 310$. 
(3) Haemosiderosis.-Haemosiderin granules, readily stainable with the Prussian blue method, were found in many synovial cells and in subsynovial macrophages, from all injected joints. The subsynovial haemosiderin deposits were always coarser and more extensive than those observed in the synovial intima. The total amount of such deposits was clearly related to the number of intraarticular injections the animal had received, being most marked in Group IV animals, which had received 24 weekly injections of blood and were killed one week after the last injection. Group V animals, which had received the same number of injections but were killed 6 months after the last injection, showed only a slightly less severe synovial haemosiderosis. It is interesting to note that even 6 months after cessation of treatment both synovial intimal cells and subsynovial macrophages contain haemosiderin.

\section{Ultrastructural Changes}

Many of the ultrastructural changes observed by us in these chronic haemarthrotic rabbit joints were similar to those seen by us in experimentally produced acute haemarthrosis in the rabbit (Roy and Ghadially, 1966) and traumatic haemarthrosis in man (Roy and Ghadially, 1967). Thus in each instance a traumatic synovitis is produced and an inflammatory cellular exudate is seen in the subsynovial tissues. Hyperplasia of synovial cells and an increase in the amount of rough endoplasmic reticulum are features common to all these conditions. However, all the above mentioned changes are more marked in chronic haemarthrosis. Erythrophagocytosis and early stages of erthrocyte breakdown are only occasionally encountered in chronic haemarthrosis. They form an important feature of acute haemarthrosis, and since they have already been described in detail by us in our previous publications we shall not deal with them here. We shall concentrate on the later more chronic changes which occur in the synovial membrane as a result of repeated injections of blood into the joint cavity.

Synovial cells.-The synovial cell hyperplasia that occurs in this condition is shown in Fig. 7 (overleaf).

The cells are separated by matrix; we did not observe the occurrence of desmosomes or tight junctions between these cells. A marked increase in the amount of rough endoplasmic reticulum (with modest or gross dilatation of the cisternae), dense bodies (siderosomes), and fine filamentous fibres are also readily apparent at this low magnification.

In some synovial cells the Golgi complex appeared to be rather small, and frequently there seemed to be a reduction in the number of large smooth-walled vacuoles also. Such changes were more frequently seen in cells containing extensive iron deposits (described later) and/or fine filamentous fibres. The same was also true of mitochondria which rarely showed abnormalities except in cells containing iron and/or fine filaments.

The lipid and glycogen content of the cells showed only slight changes. There seemed to be a modest increase in the number of lipid droplets and many synovial cells showed a few scattered granules of glycogen but no massive deposits were encountered.

There was no detectable increase in the number of lysosomes similar to those found in the normal synovial cell, and only occasionally were cytolysomes presumably arising from areas of focal cytoplasmic degeneration detected. As already mentioned, phagolysomes containing segmented erythrocytes or intensely electron-opaque membranes and granules derived from them were only infrequently encountered. Illustrations of such bodies and the way they evolve were depicted in our previous paper (Roy and Ghadially, 1966).

Perhaps the most interesting and relevant finding was the occurrence of numerous siderosomes and electron dense iron-containing particles in the cytoplasm of synovial cells and in subsynovial magrophages, which we shall now describe.

Electron dense iron-containing particles.-Many more cells show electron dense particles lying free in the cytoplasm in chronic than in acute haemarthrosis. Some cells contain innumerable such particles uniformly distributed throughout the cytoplasm (Fig. 8, overleaf).

There is frequently a marked paucity of normal organelles in such cells, and any remaining organelles show pathological alterations. Thus the cell in Fig. 8 shows dilated cisternae and disintegrating mitochondria. The nucleus in such a cell is usually unaltered. The cell may therefore be regarded as degenerate rather than necrotic.

Siderosomes.-Many of the siderosomes seen in chronic haemarthrosis show the same general morphology of siderosomes seen in acute haemarthrosis (Fig. 9, overleaf). Thus these single membranebound structures contain innumerable electron dense iron-containing particles and occasionally also a few membranous structures. However, in chronic haemarthrosis of long standing (Group IV), the electron 


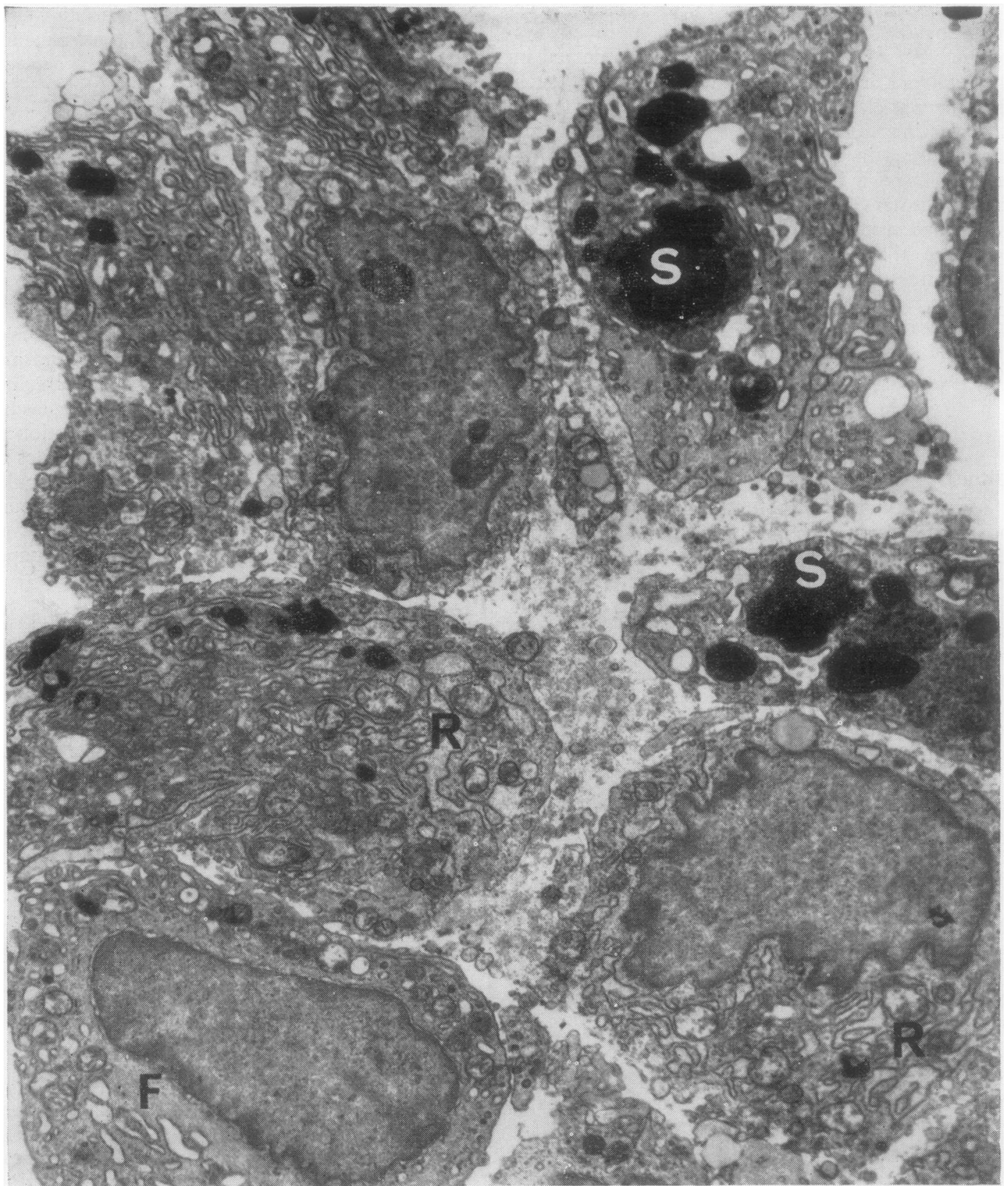

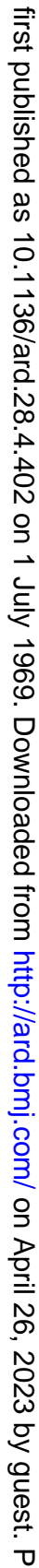

Fig. 7- Low-power electron micrograph from a Group IV animal, showing numerous small and large siderosomes (S) in synovial cells. There is also an increase in the amount of rough endoplasmic reticulum $(R)$ and fine filamentous fibres $(F)$. $\times 9,500$. 


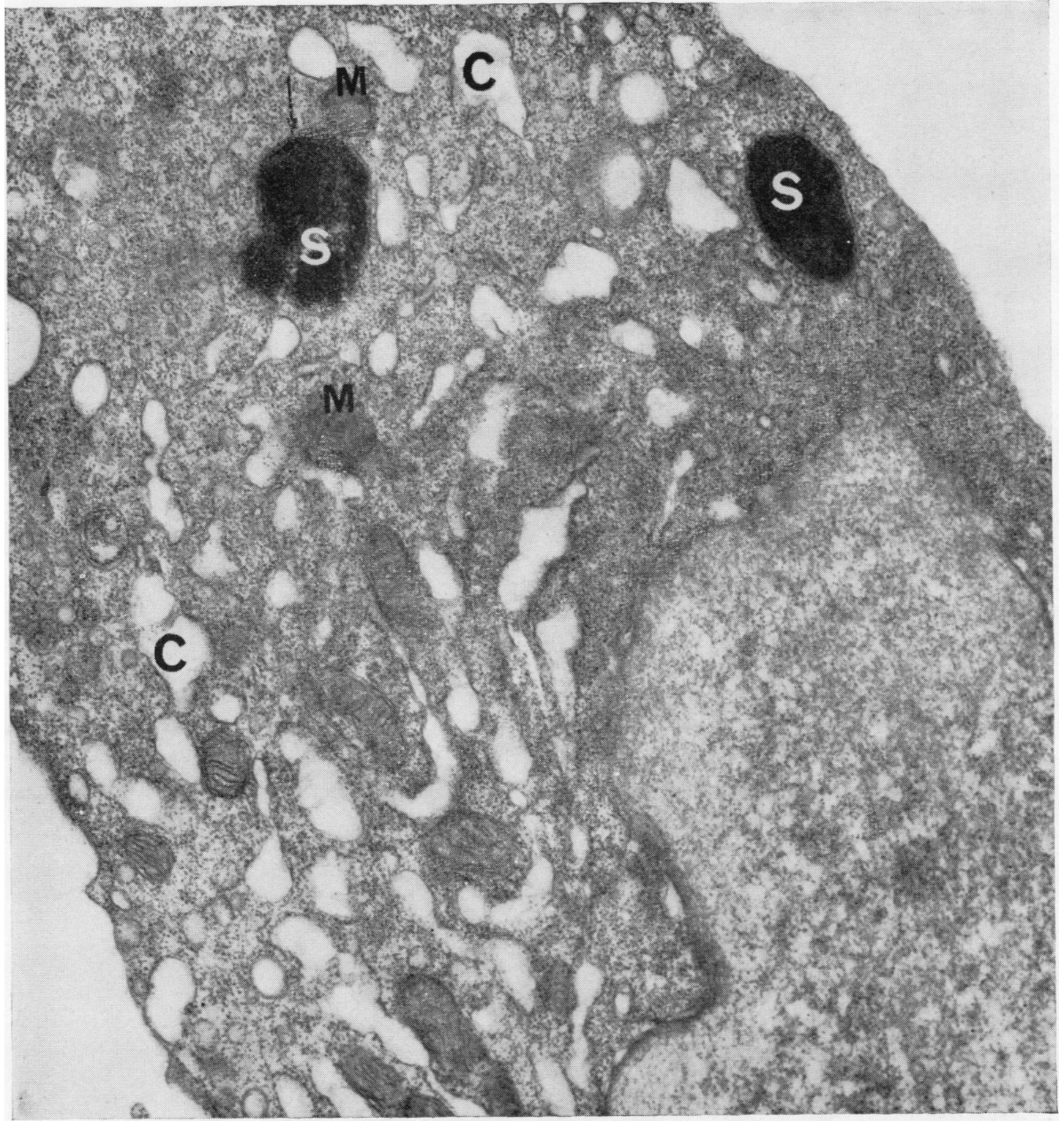

Fig. 8.-Synovial cell from a Group I animal, showing two siderosomes (S) and innumerable electron dense iron-containing particles lying in the cytoplasm. The single membrane surrounding the siderosomes can be just discerned (arrow). Note dilated cisternae (C) with electron lucent content and disintegrating mitochondria (M) suggesting cellular degeneration. $\times 38,000$.

dense particles become compacted and the siderosomes develop a more electron opaque appearance in which individual particles are difficult to discern or are undiscernible (Fig. 10, overleaf).

Siderosomes vary markedly in size and very large ones are occasionally encountered. Such siderosomes show no lobulation and the particles within them are fairly uniformly distributed. In such cases there is no reason to suspect that they have been derived by fusion of smaller siderosomes. However, Fig. 11 (overleaf) shows that such a process of fusion does at times occur to produce a lobulated structure which might be called a compound siderosome. At times not only numerous siderosomes but also other cell 


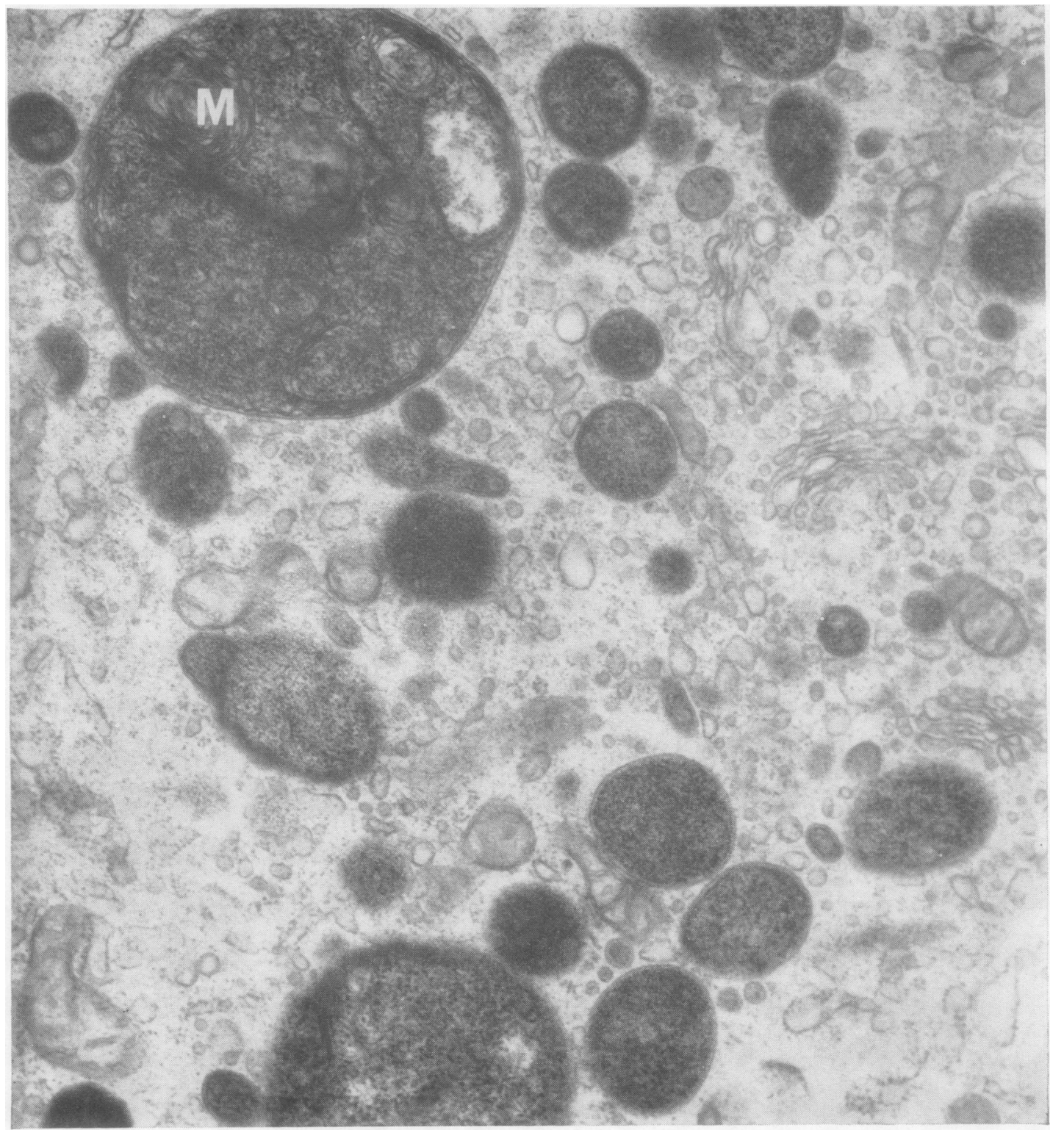

Fig. 9.-Collection of siderosomes, some containing membranous structures (M), in a synovial cell from a Group IV animal. The electron dense particles are easily seen as they are set in a medium density matrix. $\times 37,000$.

organelles and inclusions are sequestrated in a single large membrane-bound body which might be called a complex siderosome (Fig. 12, overleaf).

Ordinary, compound, and complex siderosomes occur in both synovial cells and macrophages, and when they are present in large numbers the cell containing them shows degenerative changes similar to that described earlier for cells containing electron dense iron-containing particles.

Changes in subsynovial tissue.-Electron microscopy confirmed the light microscopic observation of $\stackrel{\mathbb{D}}{\Omega}$ inflammatory ctllular infiltration of the subsynovial $\underset{\sigma}{\sigma}$ 


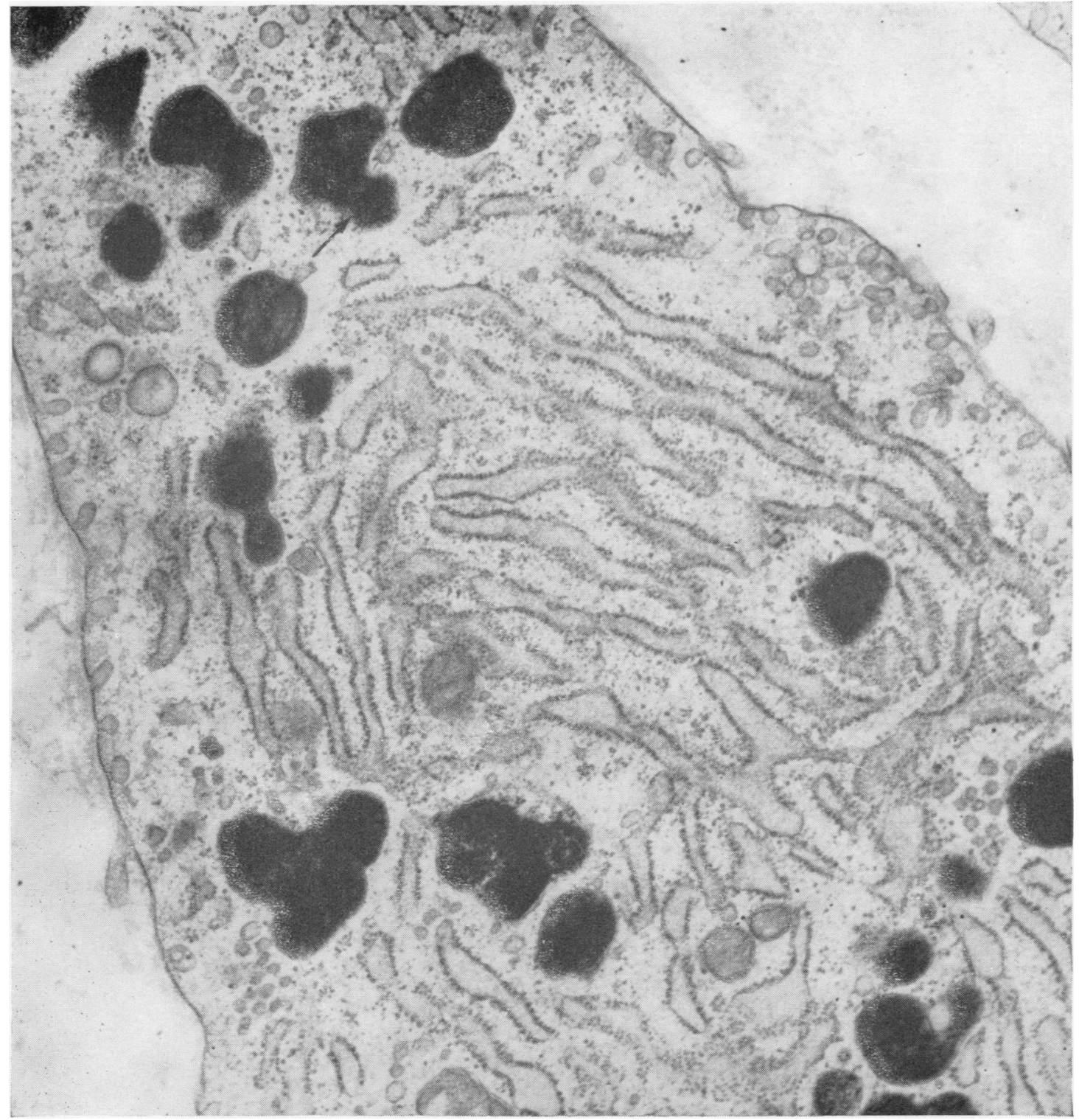

Fig. 10.-Type B synovial cell from a Group IV animal, showing numerous siderosomes where the iron-containing particles have become compacted to form electron dense masses. The electron dense particles can, however, be just discerned in some of the sidero-

tissue. The inflammatory reaction that occurs in this tissue ultimately leads to fibrosis. Examination of the experimental material revealed that the degree of fibrosis is related to the duration and intensity of treatment and persists even after cessation of injections of blood into the joint. Siderosomecontaining macrophages are also more frequently encountered in animals which have been treated for a prolonged period by repeated injections of blood. Many such macrophages persist in the subsynovial tissue even 6 months after discontinuance of the regime of weekly injections. The subsynovial blood vessels appear to be larger and more numerous. There is also some increase in perivascular fibrous tissue. Rod-shaped bodies are seen in some of the vascular endothelial cells. 


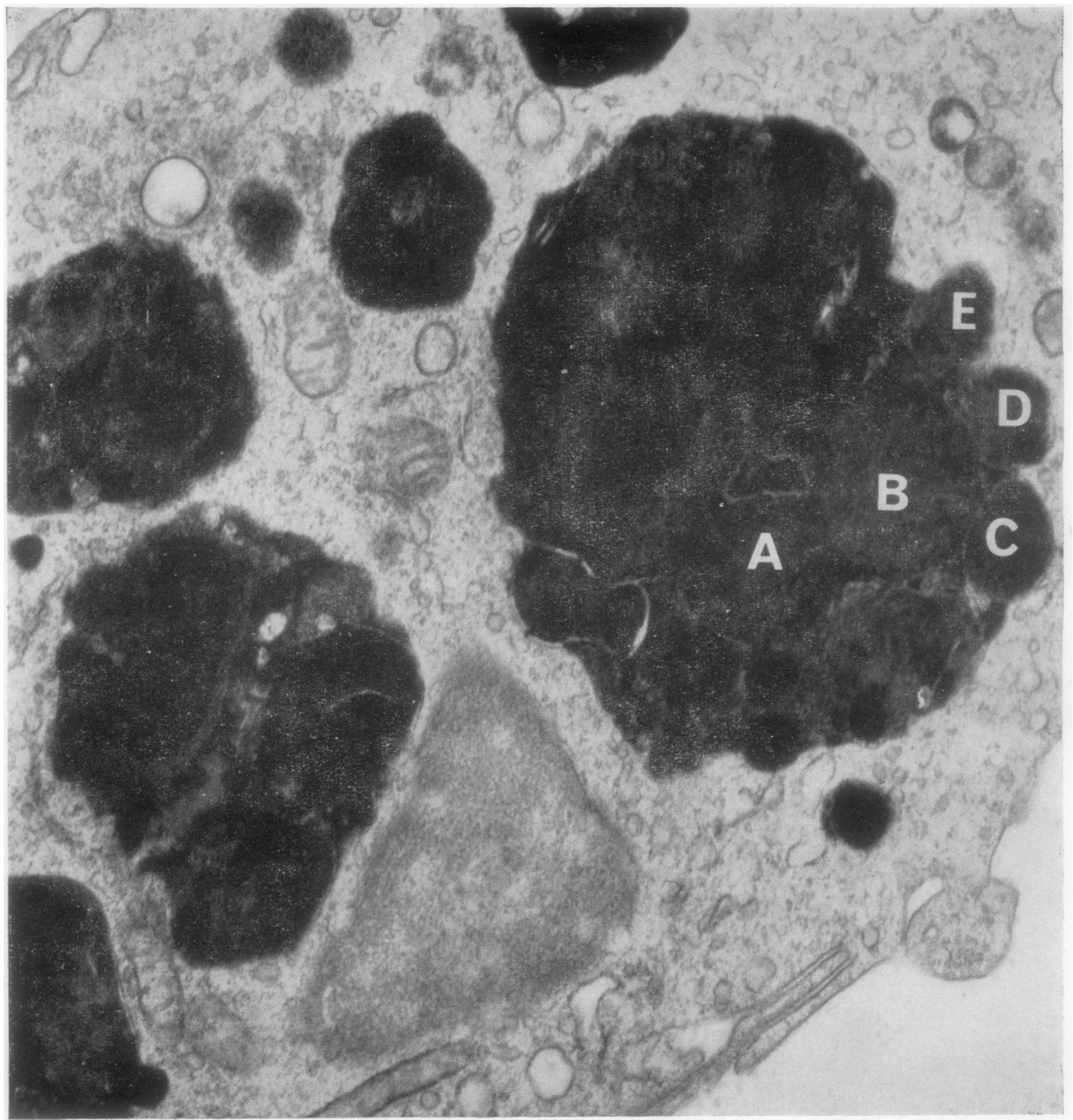

Fig. 11.-Group IV animal. Large compound siderosomes composed of several siderosomes, some of which are indicated as A, B, C, D, and $\mathrm{E} . \quad \times 27,000$.

\section{Discussion}

The changes observed by us with the light microscope in the synovial membrane in the present experiments are similar to those known to occur in haemophilic joints (Key, 1932; Ghormley and Clegg, 1948; De Palma and Cotler, 1956; Rodnan and others, 1959) and in experimental haemarthrosis produced by other authors (Key, 1929; Wolf and Mankin, $\stackrel{\oplus}{\complement}$ 1965; Hoaglund, 1967). These include proliferation $\stackrel{\oplus}{\oplus}$ of synovial cells, fibrosis of subsynovial tissues, and 7 the accumulation of haemosiderin in synovial cells ${ }_{0}^{\circ}$ and subsynovial macrophages.

Chronic haemarthrosis has been previously induced $\frac{\circ}{\mathbb{D}}$ in dogs by Young and Hudacek (1954) and in the $\frac{\Omega}{\sigma}$ 


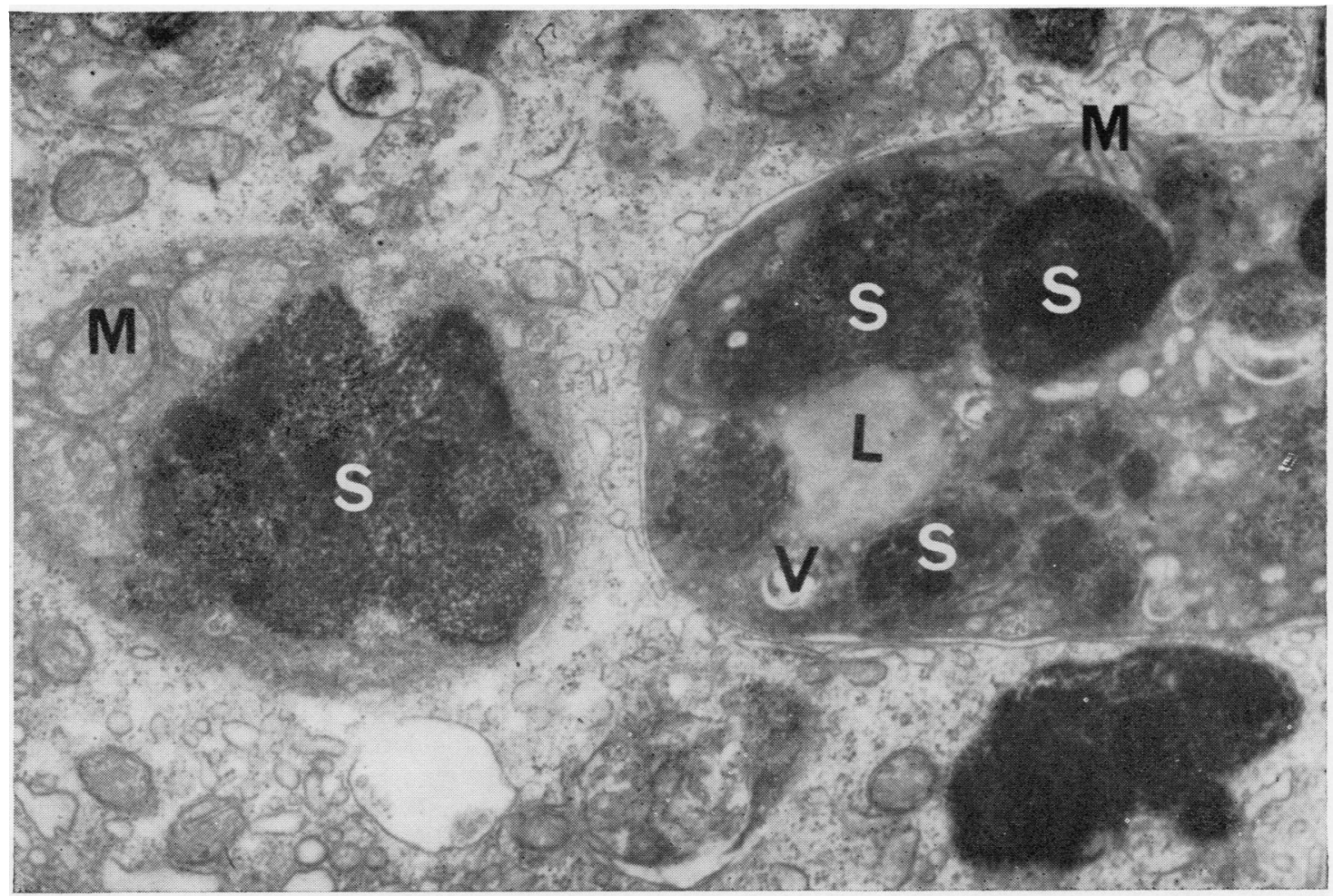
Fig. 12.-Group II animal. Complex siderosomes contain several siderosomes (S), lipid droplets (L), mitochondria (M), and vesicles (V).

rabbit by Key (1929), Volz and Peltier (1963), Wolf and Mankin (1965). Besides studying the pathology of haemarthrosis such experiments have also been aimed at testing the idea that villonodular synovitis might be produced by repeated haemarthrosis.

In our study some histologically detectable villous proliferation and also a few focal accumulations of histiocytes and giant cells were found, but no overt change that could be labelled villonodular synovitis was observed in any animal. This is in keeping with the findings of Key (1929) and Wolf and Mankin (1965), who also failed to produce the picture of villonodular synovitis in their experimental material. On the other hand, Young and Hudacek (1954) and Volz and Peltier (1963) apparently succeeded in producing a condition similar to villonodular synovitis in their experimental animals. It is possible that the more intensive and prolonged regime of injection of blood adopted by these workers may have been responsible. However, this cannot be the only factor involved for in human haemophiliacs recurrent haemarthrosis may occur for many years without producing villonodular synovitis.

Prussian Blue Reaction.-When tissues containing haemosiderin are subjected to the Prussian blue test, both discrete blue granules and/or a diffuse blue hue is seen in the cytoplasm of some cells. This latter type of staining has been ascribed to a diffusion of Prussian blue from the granules, or to differences in the diffusion of various constituents of haemosiderin (Lillie, 1954). Such hypotheses are now unnecessary, for electron microscopical studies provide a much more plausible explanation for this phenomenon. It is clear that the diffuse deposits of haemosiderin particles scattered in the cytoplasm are too small to be resolved by light microscopy, but when present in sufficient quantity are likely to produce enough Prussian blue to give the cell a faint blue tint. Aggregates of small, large, and compound or giant siderosomes are of a size that can be resolved by the light microscope and produce the characteristic discrete blue granules or larger blue masses in the Prussian blue test. 
Iron-containing Electron Dense Particles.-These dense particles have been observed not only in the synovial cells in haemarthrosis but also in the cells of many other tissues in various diseases and experimental situations. Iron-containing electron dense particles may be found lying free in the cytoplasm or within single membrane-bound bodies called siderosomes. It is now clear that these particles are ultimately responsible for the positive Prussian blue reaction seen on light microscopy.

Electron microscopical examination of such iron deposits has revealed characteristic iron tetrads or hexads of ferritin (Richter, 1957; Kerr and Muir, 1960; Bessis and Breton-Gorius, 1962), and the impression is created that haemosiderin and ferritin are more or less identical. Thus Richter (1958) stated (1) that "the iron micelles of haemosiderin and ferritin are composed of the same subunits" and (2) that "ferritin is a component of haemosiderin and at times the prominent one".

However, chemical differences between the two make it difficult to accept this hypothesis in its entirety, and Shoden and Sturgeon (1961) have suggested that the haemosiderin granule is a relatively amorphous condensate of ferric hydroxide virtually free of protein, and that it probably arises by a process of degradation of the protein matrix of ferritin. We find this view more acceptable and therefore prefer to call these particles either "ironcontaining electron dense particles" or "haemosiderin particles", rather than ferritin or ferritin aggregates.

We noted earlier that electron dense iron-containing particles are found not only in siderosomes but also lying free in the cytoplasm of some cells. The mechanism by which such particles are deposited in the cytoplasm of synovial cells is not clear. One could argue that haemoglobin from lysed erythrocytes might be taken up via micropinocytotic vesicles or other means and then degraded and deposited as haemosiderin, or that the conversion from haemoglobin to ferritin or haemosiderin occurs outside the cell and that this is then picked up by the synovial cell. In either instance one would have to explain how such a breakdown of haemoglobin is accomplished. The notion that the free-lying particles occur as a result of rupture of siderosomes is perhaps more satisfying, for hydrolytic enzymes capable of degrading protein occur at this site, and in electron micrographs one does occasionally find objects which can be interpreted as ruptured siderosomes. However, such an appearance could be an artefact, and also it is difficult to visualize how focal rupture of occasional siderosomes would produce a homogeneous peppering of the entire cell with dense particles.
Nature and Origin of Siderosomes.-The term siderosome was proposed by Richter (1957) to क describe membrane-bound bodies with aggregates $\ddot{\Rightarrow}$ of iron-containing electron dense particles (mean $\stackrel{0}{\stackrel{(}{+}}$

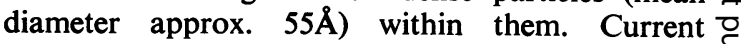
opinion regards the siderosomes as a lysosomal body $\underline{\bar{N}}$ in which haemoglobin and/or its derivatives are $\frac{\bar{c}}{\vec{D}}$ digested and degraded to simple iron compounds. $\stackrel{\mathbb{Q}}{\stackrel{2}{2}}$ This view is supported by the fact that acid phos- \& phatase has been demonstrated in the siderosomes in cells of liver and kidney tubules (Novikoff, Beaufay, and de Duve, 1956; Ericsson, 1965).

The precise manner in which siderosomes originate and evolve is not quite clear although it seems that they may be produced in a variety of ways.

Erythrophagocytosis by synovial cells leads to a variety of lysosomal bodies (Roy and Ghadially, 1966) containing different proportions of whorled membranes and iron-containing electron dense particles. Bodies rich in such particles would appear as siderosomes. Droplets of haemoglobin are at times extruded from the phagocytosed erythrocytes into the synovial cell. It is easy to visualize how such droplets could turn into siderosomes. Finally, haemoglobin from lysed erythrocytes may be picked up by the synovial cell and turned into siderosomes.

The sequence of events which brings siderosomes and/or other organelles together to form compound and complex siderosomes are not as yet established. One could, however, speculate that hydrolytic enzymes probably escape from some of these lysosomal bodies (siderosomes) and that neighbouring organelles and siderosomes are damaged. Such an area of focal cytoplasmic degeneration could then be resequestrated into a larger lysosomal body which, depending on its contents, would be labelled compound or complex siderosome. Such structures could then be regarded as varieties of cytolysomes.

\section{Summary}

Chronic haemarthrosis was produced in the rabbit by repeated injections of autologous blood into the knee joint. Ultrastructural studies on the synovial membrane from these animals showed a marked hyperplasia of the synovial intimal cell. There was an increase in the number of intermediate and type B cells. There was also a modest increase in the amount of fine filamentous fibre and lipid droplets. Numerous siderosomes and electron dense ironcontaining particles were seen in the synovial cells and in subsynovial macrophages. Compound siderosomes derived from the fusion of pre-existing siderosomes and complex siderosomes containing siderosomes and other cell organelles were also noted in these cells. Inflammatory cellular exudate and 
fibrosis were common features observed in all the experimental animals. The fibrosis and haemosiderosis produced by the intra-articular injection of blood was seen to persist almost unaltered 6 months after cessation of the injection regime.
This work was supported by a grant from the Arthritis and Rheumatism Council. We are grateful to Mr. T. E. Durrant for his technical assistance.

\section{REFERENCES}

Bessis, M., and Breton-Gorius, J. (1962). Blood, 19, 635 (Iron metabolism in the bone marrow as seen by electron microscopy. A critical review).

De Palma, A. F., and Cotler, J. M. (1956). Arch. Surg., 72, 247 (Hemophilic arthropathy).

Collins, D. H. (1951). J. Bone Jt Surg., 33B, 436 (Haemosiderosis and haemochromatosis of synovial tissues).

Ericsson, J. L. E. (1965). Lab. Invest., 14, 16 (Transport and digestion of hemoglobin in the proximal tubule. II. Electron microscopy).

Ghormley, R. K., and Clegg, R. S. (1948). J. Bone Jt Surg., 30A, 589 (Bone and joint changes in haemophilia).

Hoaglund, F. T. (1967). Ibid., 49A, 285 (Experimental haemarthrosis. The response of canine knees to injections of autologous blood).

Kerr, D. N. S., and Muir, A. R. (1960). J. Ultrastruct. Res., 3, 313 (A demonstration of the structure and deposition of ferritin in the human liver cell).

Key, J. A. (1929). J. Bone Jt Surg., 11, 705 (Experimental arthritis. The reaction of joints to mild irritants).

__ (1932). Ann. Surg., 95, 198 (Hemophilic arthritis (bleeder's joint) ).

Lillie, R. D. (1954). "Histopathologic technic and practical histochemistry", p. 243. Blakiston, New York.

Novikoff, A. B., Beaufay, H., and de Duve, C. (1956). J. biophys. biochem. Cytol., 2, no. 4, pt 2, Suppl., p. 179 (Electron microscopy of lysosome-rich fractions from rat liver).

Richter, G. W. (1957). J. exp. Med., 106, 203 (A study of hemosiderosis with the aid of electron microscopy).

(1958). J. biophys. biochem. Cytol., 4, 55 (Electron microscopy of hemosiderin. Presence of ferritin and occurrence of crystalline lattices in hemosiderin deposits).

Rodnan, G. P., Brower, T. D., Hellstrom, H. R., Didisheim, P., and Lewis, J. H. (1959). Arthr. and Rheum., 2, 152 (Post-mortem examination of an elderly severe hemophyliac with observation on the pathologic findings in hemophiliac joint disease).

Roy, S., and Ghadially, F. N. (1966). Ann. rheum. Dis., 25, 402 (Pathology of experimental haemarthrosis).

(1967). J. Bone Jt Surg., 49A, 1636 (Ultrastructure of synovial membrane in human hemarthrosis).

Shoden, A., and Sturgeon, P. (1961). Nature (Lond.), 189, 846 (Formation of haemosiderin and its relation to ferritin).

Volz, R. G., and Peltier, L. F. (1963). Surg. Forum, 14, 452 (Experimental production of pigmented villonodular synovitis in rabbits).

Wolf, C. R., and Mankin, H. J. (1965). J. Bone Jt Surg., 47A, 1203 (The effect of experimental hemarthrosis on articular cartilage of rabbit knee joints).

Young, J. M., and Hudacek, A. G. (1954). Amer. J. Path., 30, 799 (Experimental production of pigmented villonodular synovitis in dogs). 


\section{La membrane synoviale dans l'hémarthrose chronique artificiellement produite}

\section{RÉSUMÉ}

L'hémarthrose chronique a été produite chez le lapin par des injections répétées de sang autologue dans l'articulation du genou. Les études ultrastructurales de la membrane synoviale de ces animaux ont démontré une hyperplasie marquée de la cellule intime de la synoviale. Il y avait une augmentation dans le nombre de cellules intermédiaires et de celles du type B. Il y avait aussi une légère augmentation de la quantité de fibres filamenteuses fines et de gouttelettes lipides. De nombreux sidérosomes et de particules denses au microscope électronique qui contenaient du fer ont été vus dans les cellules synoviales et les macrophages subsynoviaux. Des sidérosomes composés et dérivés de la fusion des sidérosomes préexistants et des sidérosomes complexes contenant des sidérosomes et d'autres organelles de cellules ont été aussi notés dans ces cellules. L'exsudat cellulaire inflammatoire et la fibrose étaient des caractères communs observés chez tous les animaux de l'expérience. La fibrose et l'hémosidérose produites par l'injection de sang dans l'articulation ont été vues persistantes et presque inaltérées six mois après la dernière injection.

\section{La membrana sinovial en la hemartrosis crónica causada experimentalmente}

\section{Sumario}

La hemartrosis crónica fue producida en el conejo mediante frecuentes inyecciones de sangre autóloga en lá articulación de la rodilla. Estudios ultraestructurales de la membrana sinovial de estos animales reveló una? marcada hiperplasia de la célula íntima sinovial. Huboळ un incremento en el número de células intermedias yo tipo B. También hubo un aumento modesto en las cantidad de fibras finas filamentosas y gotitas lípidas $\overrightarrow{0}$ Numerosos siderosomas y partículas de gran densidadelectrónica, que contenían hierro, fueron observados en $\vec{\omega}$ las células sinoviales y en los macrófagos subsinoviales. También se notaron en estas células siderosomas compuestos, derivados de la fusión de siderosomas pre-Qํ. existentes y siderosomas complejos que contenían $N_{\infty}$ siderosomas y otros organelos celulares. El exudo celular inflamatorio y la fibrosis eran características comunes observadas en todo los animales del experi-o mento. Se observó que la fibrosis y la hemosiderosis producidas por la inyección intraarticular de sangre? persistía casi sin alteraciones seis meses después de habercesado el régimen de inyecciones. 